\title{
Multiple Myeloma IgA Lambda: about a Case Revealed by a Physical Asthenia and Review of an Literature
}

\author{
Djibrilla Almoustapha $\mathrm{A}^{1^{*}}$, Hamissou M. $\mathrm{R}^{2}$, Daou $\mathrm{M}^{2}$, Brah $\mathrm{S}^{3}$, \\ Kabaou $\mathrm{S}^{2}$, Malam-Abdou B ${ }^{1}$, Adehossi EO ${ }^{3}$ \\ ${ }^{1}$ Department of Onco-Hematology of the National Hospital, Niamey, Niger \\ ${ }^{2}$ Department of Internal Medicine at National Hospital, Niamey, Niger \\ ${ }^{3}$ Department of Internal Medicine at the General Reference Hospital \\ ${ }^{4}$ Department of Endocrinology of the General Reference Hospital
}

DOI: $\underline{\text { 10.36348/sjmps.2020.v06i03.009 }}$ | Received: 15.03 .2020 | Accepted: 22.03 .2020 | Published: 30.03 .2020

*Corresponding author: Djibrilla Almoustapha Amadou

\section{Abstract}

Multiple myoglobin immunoglobulin A ( $\operatorname{IgA}$ ) is a multiple myeloma entity characterized by its clinical severity but also its poor prognosis level, it is usually revealed by bone pain. We report one case of multiple myeloma with immunoglobulin A revealed by renal insufficiency, diagnosed and treated at the hematology oncology department of Hospital National of Niamey.

Keywords: Multiple Myeloma, IgA, HNN, Niger.

Copyright @ 2020: This is an open-access article distributed under the terms of the Creative Commons Attribution license which permits unrestricted use, distribution, and reproduction in any medium for non-commercial use (NonCommercial, or CC-BY-NC) provided the original author and source are credited.

\section{INTRODUCTION}

Multiple myeloma (MM) or Kahler's disease is a malignant hemopathy, characterized by a monoclonal proliferation of plasma cells invading the bone marrow and secreting a monoclonal immunoglobulin (Ig) [1]. This Ig can be of the IgG, IgA or IgD or even IgE types and / or of light kappa or lambda chains as well as forms devoid of excretions of immunoglobulins [2]. It is a rare condition, it represents $15 \%$ of malignant hemopathies including $80 \%$ of malignant monoclonal gammopathies. Its incidence increases with age, it is 5 per 100,000 inhabitants at age 50 [2]. It preferentially affects elderly subjects with a peak frequency between 67 and 70 years [2]. The clinical manifestations are dominated by bone pain, most often indicative of the disease. The presence of a marrow plasmocytosis greater than $10 \%$, a serum and / or urinary monoclonal immunoglobulin associated with clinical manifestations secondary to the proliferation of the plasma are necessary for the diagnosis. The treatment of multiple myeloma has been improved in recent years with the advent of specific innovative therapies such as immunotherapy, but above all the introduction of new therapeutic molecules $[1,3]$. We report a case of MM to IgA followed by the Onco-hematology service of the Niamey National Hospital (HNN) in which physical asthenia led to the diagnosis, in complete remission under CTD (Cyclophosphamide-Thalidomide-
Dexamethasone) having the subject of a bone marrow autograft.

\section{ObServation}

He was a 65 year old patient with ATCD in high blood pressure for 20 years on coversyl $5 \mathrm{mg}$ compliant to treatment and follow-up. The reason for the consultation was an isolated intense physical asthenia evolving for 5 months. The clinical examination found an apyretic patient, conscious with good coloration of the mucous membranes, $\mathrm{PA}=140 /$ $70 \mathrm{mmHg}$ (under coversyl), HR: $80 \mathrm{bt} / \mathrm{min}$, no lower limb edema (IMO). A deterioration of the general state (AEG) stage 2 WHO. The Blood Formula Count (NFS) revealed an anemia $(\mathrm{Hb}: 7.7 \mathrm{~g} / \mathrm{dl}$ ) normochromic normocytic aregenerative without hyperleukocytosis, $\mathrm{VS}$ at $150 \mathrm{~mm}$, an LDH level at 160UI / L and the C Reactive Protein (CRP) negative. A myelogram objectified a $48 \%$ dystrophic plasma cell medullary infiltration, an electrophoresis of serum proteins and an immunofixation of serum proteins had objectified respectively a monoclonal gamma globulin globulin (Photo-1) and a monoclonal lambda type IgA immunoglobulin (Photo-2). A hypoalbumunemia at $31.33 \mathrm{~g} 1, \quad \beta 2$ microglobulin at 4.2. The calcemia corrected to $2.75 \mathrm{mmoh}$. The radiological assessment was normal. 
Based on the hemogram, myelogram and immunoelectrophoresis data for serum proteins, the diagnosis was that of an IgA lambda MM, stage IIIB of Salmon and Durie and stage II of the ISS. The patient was put on alkalinization treatment associated with a CTD protocol (Cyclophosmamide-ThalidomideDexamethasone) from which he received 18 courses.
The patient was in complete spinal remission after 18 months of treatment with a regression of VS and Normalization of NFS. Given the limited technical platform for performing a bone marrow autograft, a transplant was performed outside, considered a success to date.

\section{Table-1: Classification de Durie et Salmon}

\begin{tabular}{|c|c|}
\hline Critères & Masse tumorale mesurée \\
\hline $\begin{array}{l}\text { Stade I } \\
\text { Tous les critères suivants : } \\
\begin{aligned} \text { - } & \mathrm{Hb}>10 \mathrm{~g} / \mathrm{Dl} \\
\text { - } & \text { Calcémie normale } \\
\text { - } & \text { Radios osseuses normales ou une seule lésion } \\
\text { - } & \text { Taux de production de protéine monoclonale faible }(\operatorname{IgG}<50 \mathrm{~g} / \mathrm{L} . \\
& \operatorname{IgA}<30 \mathrm{~g} / \mathrm{L} . \mathrm{Bj}<4 \mathrm{~g} / 24 \mathrm{~h})\end{aligned}\end{array}$ & $0,6 \times 10^{12 / \mathrm{m} 2}$ \\
\hline $\begin{array}{l}\text { Stade II } \\
\text { Ni stade I ni Stade II }\end{array}$ & 0,6 à $1,2 \times 10^{12} / \mathrm{m} 2$ \\
\hline 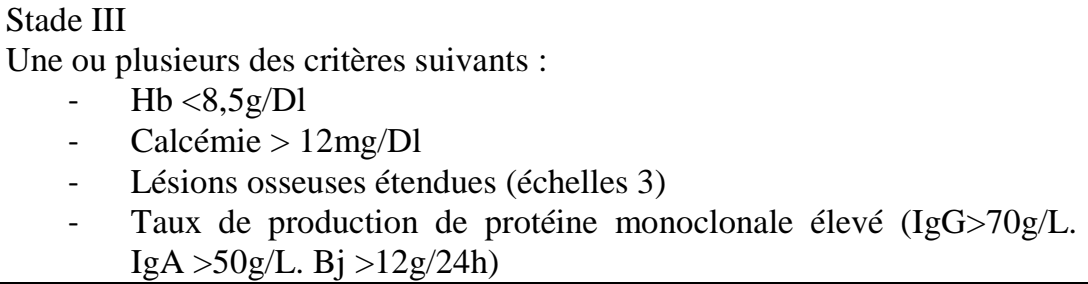 & $>1,2 \times 10^{12} / \mathrm{m} 2$ \\
\hline $\begin{array}{l}\text { Sous classification (A ou B) } \\
-\quad \text { A : créatinémie }<20 \mathrm{mg} / \mathrm{L} \\
\text { - } \quad \text { B : créatinémie }>20 \mathrm{mg} / \mathrm{L}\end{array}$ & \\
\hline
\end{tabular}

Table-2: Score pronostique international (International Staging Systèm 2003)

\begin{tabular}{|l|l|l|l|}
\hline & Stade I & Stade II & Stade III \\
\hline \multirow{3}{*}{ Critères } & B2-microglobuline & B2-microglobuline < 3,5 mg/L et albumine < 3,5 & B2-microglobuline $>$ \\
& $\begin{array}{l}3,5 \mathrm{mg} / \mathrm{L} \text { et albumine }>3,5 \\
\text { g/L }\end{array}$ & $\begin{array}{l}\text { g/L ou B2-microglobuline comprise entre 3,5 et } \\
5,5 \mathrm{mg} / \mathrm{L}\end{array}$ & $5,5 \mathrm{mg} / \mathrm{L}$ \\
\hline & $\mathbf{6 2}$ mois & $\mathbf{4 5}$ mois & $\mathbf{2 5}$ mois \\
\hline
\end{tabular}

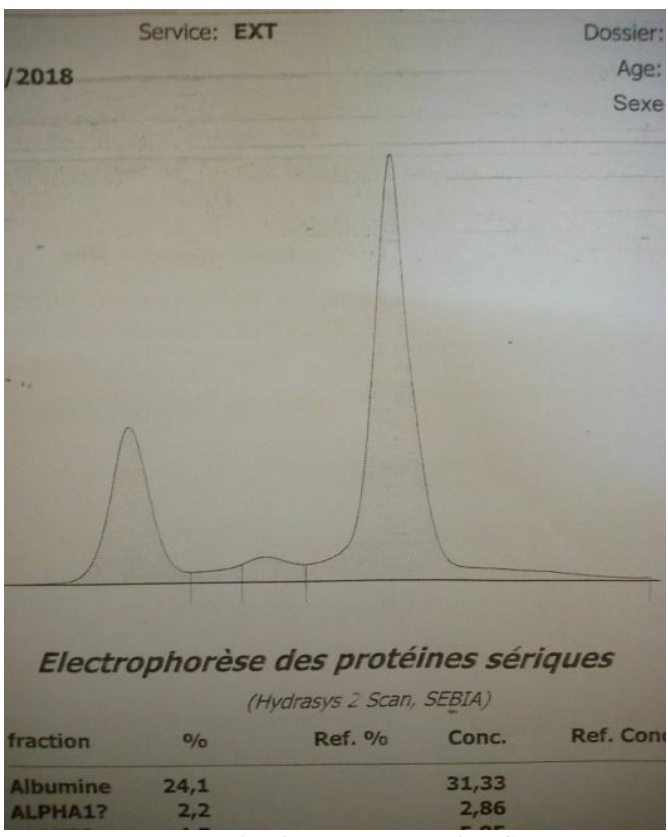

Photo-1: Pic gamma sur l'EPS

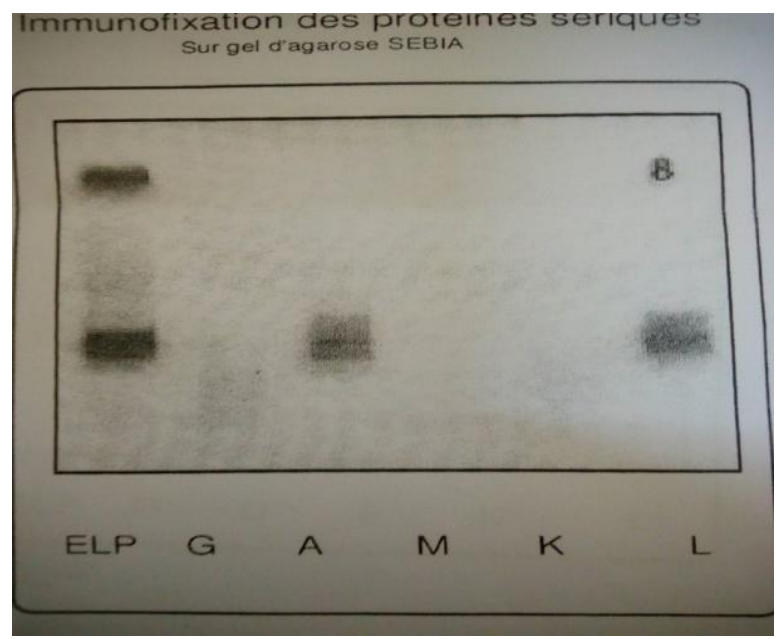

Photo-2: IgA sérique de type lambda

\section{DISCUSSION}

$\mathrm{MM}$ is a malignant hemopathy, which relatively affects the elderly. Its frequency is increasing 
and increases with age. The peak frequency varies by country from 65 to 70 years of age. Cases observed before 40 years are rare (2\%) [4]. However, MM was discovered in our patient at 65 years of age. The predominance is particularly masculine [3]. The deterioration of the general state is frequent in our regions is partly linked to the diagnostic delay. The clinical symptomatology of MM is dominated by bone signs in 70\% [4-5], which is not the case for our patient. The anemia in our patient was normocytic arregenerative normochromic. Diawara et al in Senegal reported this type of anemia in $80 \%$ of patients with multiple myeloma IgA type [6]. Anemia is the most common abnormality in the hemogram. In the historical series of the Mayo clinic, $62 \%$ of patients had a hemoglobin level lower than $12 \mathrm{~g} / \mathrm{dl}$, but in a more recent series, only $39 \%$ had anemia due to an earlier diagnosis [6, 7]. Multiple mechanisms explain the occurrence of anemia, including spinal cord cell proliferation, relative erythropoietin deficiency, suppression of cytokine-induced erythropoiesis, haemodilution, the effect of renal failure and expression on the surface of the myeloma cell receptors of the Fasligand and TRAIL receptors is involved in the appoptosis of erythroid progenitors [6, 7]. Leukopenia and thrombocytopenia are rare and have a poor prognosis [7]. Some authors believe that anemia has a negative prognostic value [7]. The myelogram is necessary to establish the diagnosis, when it highlights a plasma cell infiltration greater than 10\% [5-7]. In our patient it was $48 \%$. Sometimes a first myelogram can turn out to be normal indicating a focal tumor infiltration. Electrophoresis and immunofixation of serum protein (EPS) and urinary protein and essential for diagnosis. In $80 \%$ of cases, EPS reveals a narrow peak corresponding to a monoclonal protein of the $\mathrm{IgG}$ or IgA type migrating in the $\gamma$-globulin zone, $\beta$ globulin, more rarely $\alpha 2$-globulin $[6,7]$. Our patient had a peak in the $\gamma$-globulin zone. Immunofixation of serum proteins allows typing the monoclonal protein, for its heavy chain and its light chain. Around 55\% of $\mathrm{MM}$ are of the IgG type, $25 \%$ of the IgA type, $15 \%$ are of the urinary type and the $5 \%$ constitute the rare variants [8]. Our patient is of the IgA Lambda type. The immunoglobulin weight test is used to assess the decrease in synthesis of normal polyclonal immunoglobulins and the resulting immune deficiency [9-11].

The Speed of Sedimentation constitutes an important biological marker, not only in classification but also in monitoring. It was accelerated in our patient. Mezouar et al at FES found accelerated VS in 52 cases, ie $100 \%$ [12]. The acceleration of VS is directly linked to the presence of the serum monoclonal protein, hence its normality in MM with light or non-excreting chains [7]. The determination of calcemia is part of the systematic examinations in the initial assessment and monitoring of MM [8]. A slight hypercalcemia was found in our patient, It is due to hyper osteoclastic resorption [12].

Touaoussa had reported in a 2015 study in Morocco on 60 cases, $30 \%$ of light chain IgA. Some authors reported an increasing frequency of cases of light chain MM, IgA regardless of age [7]. LDH should lead to the possibility of extramedullary damage, which will make it possible to initiate specific therapy [8]. Our patient had a normal LDH level. The $\$ 2$ microglobulin whose concentration was determined in our patient was high, it is a marker of lymphoplasmocytic proliferation and makes it possible to assess the tumor mass in MM but also a marker for therapeutic monitoring and reliable prognosis $[7,8,11]$. When its level is lower than $6 \mathrm{mg}$, the median survival is 46 months whereas it is only 18 months if it is higher than $6 \mathrm{mg}$. Its interest as a prognostic factor has been confirmed by several authors [12].

The prognosis of myeloma is determined both by the number of myeloma cells and by the intrinsic characteristics thereof, which include the proliferation index, the rate of production of monoclonal protein, and the production or not of various cytokines or molecules affecting the normal functioning of different tissues and / or organs. Table-1 presents the classification of Durie and Salmon. According to clinical and biological data, our patient is in stage IIIB of Durie and Salmon which is of poor prognosis, with a limited lifespan.

A combination of serum beta-2-microglobulin and albumin levels seemed the most promising, and fell into a three-stage classification. This new ISS classification (International Staging System) was validated and becomes more widely accepted (Table-2) [13]. According to beta-2-micoglobulin and albumin data, our patient is classified as stage II with poor prognosis.

Our patient had received chemotherapy based on the CTD protocol (Cyclophosphamide, Thalidomide and Dexamethasone) having resulted in complete remission after 2 months of treatment. It is a protocol which is very rarely described in the literature, but several studies have highlighted the effectiveness of thalidomide as monotherapy in the management of relapsed MM including the Bartology team in 1999, updated in 2001 [12] out of a total cohort of 169 patients. Several European studies will confirm these results [12]. The use of thalidomide monotherapy generates a partial response rate (greater than 50\%) of around 30 to $35 \%$ in a fairly short time, on average two to three months. The average response time is approximately one year and $20 \%$ of patients remain non-progressive at two years. The quality of the response, like the intensity of the toxicity, appears to be dose dependent, however efficacy of thalidomide at very low dosage (50 $\mathrm{mg} /$ day) has been reported [12]. 
Combination with high sequential dose dexamethasone increases partial response rates around 50-55\% [10-12]. The efficacy of thalidomide in relapsed myeloma having been established, two studies had rapidly evaluated its first-line use associated with dexamethasone $[12,13]$. Response rates are in the range of 60 to $70 \%$ including 10 to $15 \%$ of complete response. Thromboembolic complications related to thalidomide increase in case of use in combination with dexamethasone (10-15\%) [10-12], where treatment with aspirin at an anti-platelet aggregating dose was initiated in our patient.

\section{CONCLUSION}

$\mathrm{MM}$ is a condition characterized by its polymorphism both clinically and biologically. The progress made in the knowledge of the disease has allowed a therapeutic stratification according to the different prognostic factors highlighted. Despite an increasingly effective treatment that has improved quality of life and increased median survival, $\mathrm{MM}$ is currently an incurable disease.

\section{REFERENCES}

1. Gaougaou, N., Bahri, L., Quessar, A., Benchekroun, S., El Bakkouri, J., \& Riyad, M. (2014). Présentation épidémiologique, clinique, biologique et pronostique du myélome multiple à Casablanca (Maroc). Journal Africain de Cancer, 6(3):159-165.

2. Chong, Y. P., Kim, S., \& Ko, O. B. (2008). Poor out-comes for IgD multiple myeloma patients following high-dose melphalan and autologous stem cell transplantation: a single center experience. Journal Korean Medical Science, 23:819-24.

3. Seynabou, F., Fatma, D., Coumba, D., Boundia, D., Awa, C., \& Fatou, S. D. (2017). Profil diagnostique et évolutif du myélome multiple au Sénégal : étude monocentrique de 2005 à 2016. Pan african medical journal, 9:3-4.

4. Slaheddine, C., Mariem E., \& Sofiene, B. (2010). Le myélome multiple: àpropos de 25 cas. Ann Gerontol, 3(1):41-44.

5. Serraj, K., Hamaz, S., Alaoui, H., Keller, O., Morot, R., \& Andrès, E. (2015). Traitement du myélome multiple: actualités et perspectives, 21(4):268-76.

6. Diawara, C. (2014). Myélome multiple Profil : épidémiologique et clinique dans le Service de Rhumatologie au CHU du Point-G. Thèse med. Université de Bamako, 78.

7. Touaoussa, A. (2015). Aspect clinicobiologique et évolutif du myélome multiple. Mémoire de spécialité en méd; Université Fès, 98-104.

8. Mathilde, P. (2011). Etude de la stabilité d'une solution de bortézomib à $1 \mathrm{mg} / \mathrm{mL}$ conditionnée en seringue de polypropylène. Mémoire du diplôme d'études spécialisées de pharmacie. Université henri poincare - nancy I.

9. Dimopoulos, B. (2004). La thalidomide dans le traitement du myélome multiple, évaluation préliminaire. OCCETS, 28(1):14-15.

10. Méhennaoui-Toumi, H., Smaïli, K., \& Boucheloukh, N. (2014). Évaluation des résultats $\mathrm{du}$ traitement du myélome multiple par le protocole VCD. Hématologie, 20(supplement 3):16-16.

11. Elmezouar, I. (2010). Myelome multiple (Aproposde 58cas), Thèse med. Université Fès, (199):34-68.

12. Djibrilla, A., Malam-Abdou, B., Jamai, I., EchChouiyakh, N., Squali, T., \& Brah, S. (2018). Un cas de Myélome multiple à IgD Lambda révélé par une insuffisance rénale. Health Sci Dis, 19(3):9294. 